\title{
HIV-2 diagnosis and quantification in high-risk patients
} Philip A Chan*1, Sarah E Wakeman1, Timothy Flanigan², Susan Cu-Uvin², Erna Kojic ${ }^{2}$ and Rami Kantor ${ }^{2}$

Address: ${ }^{1}$ Department of Internal Medicine, The Warren Alpert Medical School of Brown, University and Rhode Island Hospital, Providence, RI 02903, USA and 2Division of Infectious Disease, The Warren Alpert Medical School of Brown University and The Miriam Hospital, Providence, RI 02906, USA

Email: Philip A Chan* - pchan@lifespan.org; Sarah E Wakeman - sarah_wakeman@brown.edu; Timothy Flanigan - tflanigan@lifespan.org; Susan Cu-Uvin - susan_uvin@brown.edu; Erna Kojic - ekojic@lifespan.org; Rami Kantor - rkantor@brown.edu

* Corresponding author

Published: 14 August 2008

AIDS Research and Therapy 2008, 5:18 doi:10.1186/1742-6405-5-18

This article is available from: http://www.aidsrestherapy.com/content/5/I//8

(C) 2008 Chan et al; licensee BioMed Central Ltd.

This is an Open Access article distributed under the terms of the Creative Commons Attribution License (http://creativecommons.org/licenses/by/2.0), which permits unrestricted use, distribution, and reproduction in any medium, provided the original work is properly cited.
Received: 3 July 2008

Accepted: 14 August 2008

\begin{abstract}
Current diagnostic assays for HIV-I do not always test for the presence of HIV-2 in the United States. We present the case of a patient from Cape Verde, who was admitted to our hospital with rapidly deteriorating neurological function and multiple white matter lesions on MRI likely secondary to progressive multifocal leukoencephalopathy (PML). Initially, the patient had a positive EIA for HIV, but a negative HIV-I Western Blot and no viral load detected on a branched-DNA assay. A repeat viral load by reverse transcriptase methodology (RT-DNA) detected 121,000 copies and an HIV-2 Western Blot was positive. The case highlights an extremely rare presentation of HIV-2 with severe neurological disease. We discuss the different tests available for the diagnosis and monitoring of HIV-2 in the United States.
\end{abstract}

\section{Background}

HIV-2, the second AIDS-causing virus, is found predominantly in the Portuguese speaking countries of West Africa, with the highest rates of infection in Guinea-Bissau [1]. The prevalence of HIV-2 in the United States is extremely low [2], and the current guidelines recommend testing for HIV-2 only in the case of an indeterminate western blot or in patients with known links to West Africa $[2,3]$. While this screening practice may make sense for the majority of U.S. cities where the percentage of the population of West African descent is decidedly small, cities with a significant immigrant community from infected regions should consider increased surveillance. We present the case of a patient of Cape Verdean descent with likely PML in the setting of HIV-2, and discuss the difficulties of diagnosing HIV-2 in the United States.

\section{Case presentation}

A 48 year-old male with a past medical history significant only for cataracts was admitted to our hospital with weakness, difficulty walking, and confusion that began one day prior to admission. In addition to the neurological symptoms, the patient had experienced a flu-like illness three to four weeks earlier accompanied by a ten to fifteen pound weight loss. The patient was afebrile with mental status changes and abnormal cerebellar findings on neurological exam including a wide-based gait, ataxia, dysmetria on finger-to-nose, and difficulty with rapid alternating hand movements. On further history, the patient took no medications and was born in Cape Verde, immigrating to the United States six years earlier. While he admitted to having multiple recent female sexual partners, he denied any drug use or any male sexual partners. His wife and five 
children remained in Cape Verde. His history raised the possibility of acute HIV infection or an AIDS-related illness.

An initial HIV enzyme immunoassay (EIA) was performed in the emergency room and returned positive (Bayer ADVIA Centaur HIV-1/O/2 EHIV EIA). Other laboratory tests were normal, aside from a slightly decreased white count of 3,800 cells/uL. A non-contrast CT of the brain on admission noted no acute abnormalities. An MRI with and without contrast of the brain was performed on the second day of admission, which showed multifocal supra and infratentorial T2 flare hyperintense lesions felt to be consistent with multiple sclerosis, an acute demyelinating process, or Lyme disease. Two lumbar punctures were subsequently performed showing four nucleated cells, an elevated protein of $103 \mathrm{mg} / \mathrm{dL}$, and a normal glucose. Testing of the cerebrospinal fluid (CSF) was negative for cytomegalovirus (CMV, PCR), EpsteinBarr Virus (EBV, PCR), varicella zoster virus (VZV, PCR), Lyme (IgM and IgG antibodies, PCR), herpes simplex virus (HSV-1 and -2, IgM and IgG antibodies), Toxoplasmosis (IgM and IgG antibodies), India Ink, Cryptococcal antigen, Streptococcal antigen, rapid plasma reagin (RPR), JC Virus (PCR), acid-fast bacilli (AFB), and cytology. Other labs sent for the evaluation of mental status change were normal including electrolytes, B12, TSH, and a urine drug screen. Serum tests looking for an infectious etiology were also negative, including an RPR, fluorescent treponemal antibody (FTA-ABS), CMV antibodies, and Lyme antibodies. A hepatitis panel revealed past infections with hepatitis $A$ and $B$, and a negative hepatitis $C$ antibody. Blood, urine, and CSF cultures were negative, as was a rapid influenza. The patient's CD4 count returned at 202 (17\%, ratio 0.3$)$.

The patient improved with supportive care over the hospital course and was discharged on day five with follow-up to an outpatient clinic. Six days later the patient was seen at HIV clinic, at which point his confirmatory western blot for HIV-1 was still pending. Based on the patient's clinical history, CD4 count, positive EIA, and recent immigration from Western Africa, it was felt that the patient was most likely suffering from an HIV-related neurological process. He was started on the anti-retroviral regimen of ritonavirboosted atazanavir (ATV), tenofovir (TDF), and emtricitabine (FTC), and a plasma viral load was sent.

Six days after the clinic visit, the patient was readmitted to the hospital for continued confusion and gait disturbance. The patient's initial confirmatory western blot for HIV-1 returned negative and the viral load was undetectable (branched DNA technology, Versant HIV-1 RNA 3.0, Bayer). Given the confusing picture and strong clinical suspicion for HIV, a second Western blot specific for HIV-
2 was sent, as well as a repeat viral load using RT-PCR analysis (Roche Amplicor RT-PCR). The patient had a repeat MRI which showed interval worsening of the white matter lesions, but no new processes. During the course of this hospitalization, the patient's second viral load returned at 121,000 copies/mL and the western blot was positive for HIV-2. The differential diagnosis based on the patient's clinical history and imaging included PML, HIV encephalitis and/or lymphoma. Given the patient's negative CSF EBV and disseminated (non-solitary) MRI lesions, it was deemed highly unlikely that the patient had CNS Lymphoma. Although the patient had a negative JC virus PCR, review of the MRI found the lesions to be most consistent with PML and/or HIV encephalitis. A brain biopsy was considered, but the patient and his family refused.

Looking back over the hospital's records, it was discovered that the patient had been seen two years prior to this admission for a unilateral facial droop. In addition, a steadily declining WBC count was noted through several emergency room visits. Based on these findings, as well as the clinical presentation, the patient was felt to have chronic, as opposed to acute, HIV-2. While the patient may have had sexual contact with other West African immigrants in this country, it seemed most likely that he had become infected while living in Cape Verde more than six years earlier.

Over the first week of the second admission, the patient worsened neurologically, becoming incontinent and acutely agitated requiring medication with anti-psychotics. A repeat MRI of the brain on day eight of admission showed rapid progression of the white matter disease, as described above. Given the patient's poor prognosis, hospice was considered. The patient was changed to ritonavirboosted lopinavir, and over the next couple weeks made significant clinical improvements, regaining continence, becoming increasingly lucid, and improving in gait and balance. By the fourth week of his admission, his CD4 count had increased to 331 (17.4\%), although his MRI showed no regression of the lesions. The patient was discharged on HAART in stable condition, but with persistent neurological deficits.

\section{Discussion}

We present a case report of an unusual and challenging diagnosis of HIV-2 in the United States. Our patient emigrated from Cape Verde, an archipelago off the west coast of Africa with an estimated population of 460,000. Cape Verde is a place defined by migration, with approximately 500,000 people living abroad, 265,000 of which are estimated to be in the United States [4]. The migration of Cape Verdeans to the United States began in the 1800's with whaling ships that carried West Africans to New Eng- 
land's shores. New Bedford, Massachusetts and Providence, Rhode Island are America's oldest Cape Verdean communities, with 1,592 legal immigrants settling in the Providence Metro area between 1991 and 1998 alone [5].

The prevalence of non-subtype B HIV in the United States is approximately $2 \%$ [6]. The virus isolated in this patient, HIV-2, is common in parts of Western Africa, but is rare in the United States [7]. HIV-2 is thought to have a milder disease course with a longer time to the development of AIDS than HIV-1 $[8,9]$. Clinical presentations of neurological syndromes with HIV-2 are extremely rare $[10,11]$. Since being discovered in 1985 [12], only 79 cases of HIV2 have been reported in the United States with 52 of those patients having originated in Western Africa [2]. Given the low prevalence of HIV-2 in industrialized countries, the clinical course and optimal treatment strategies are unknown [12]. Non-nucleoside reverse transciptase inhibitors (NNRTI's) are not effective against HIV-2, whereas nucleoside reverse transciptase inhibitors (NRTI's) may be less effective $[13,14]$. Protease inhibitors have varying efficacy against HIV-2 [15-18] and use should be guided by genotype/phenotype profiles, not commercially available in the United States. Ritonavirboosted atazanavir was initially started in this patient before the diagnosis of HIV-2, but was later changed to ritonavir-boosted lopinavir which has better efficacy against HIV-2 [16].

The identification of HIV-2 represents a diagnostic dilemma in the United States. The standard diagnosis of HIV-1 infection relies on a positive EIA followed by a confirmatory western blot assay in which two of the three HIV antigens (p24, gp41, and gp120) must be present. Screening EIA assays, including the newer rapid tests, are not always sensitive for detecting HIV-2 or group O HIV-1 [19-22], however the newer $4^{\text {th }}$ generation assays are better [5,23-25]. Routine western blots are specific mainly for HIV-1 antibodies and indeterminate western blots (i.e. detection of only one antigen, usually p24) may suggest infection with HIV-2. The only FDA-approved EIA assays that are able to detect HIV-2 are Abbott HIVAB HIV-1/2 (rDNA) EIA, Genetic Systems HIV-1/2 Peptide EIA, and Genetic Systems HIV-2 EIA.

Current CDC guidelines [26] state that HIV-2 serology should be checked in patients who: 1) Are from areas of high prevalence, mainly Western Africa; 2 ) Share needles or have sexual partners known to be infected with HIV-2 or are from endemic areas; 3 ) Received transfusions or other non-sterile medical care from endemic areas; 4) Are children of women with risk factors for HIV-2 infection. As sometimes clinical history is not available in patients with a high-suspicion for HIV infection and negative or indeterminate serology for HIV-1, additional testing should be performed for HIV-2.

Regarding viral RNA quantification, there are no FDA approved assays for the determination of HIV-2 viral load in the United States (Table 1). This creates a dilemma in the treatment of HIV-2 infected patients as viral loads are an integral part of patient monitoring. The five methods for detecting viral loads all routinely detect HIV-1 viral RNA from most group M subtypes, although small differences may exist in quantification capabilities [27-32]. Assays for HIV-2 are mainly developed for research purposes and none are commercially available [15,28,33-35]. The NucliSens EasyQ assay (BioMerieux, Netherlands) is approved for HIV-1 viral load quantification and has been shown to detect subtype A of HIV-2 by nucleic acid amplification [36]. Similarly, the Roche Amplicor assay was able to detect three of four HIV-2 samples [37]. Neither the branched DNA nor other RT-PCR assays have been shown to detect HIV-2, and none are approved by the FDA or regularly used to detect HIV-2. Differences between the assays are likely due to primers which are more likely to anneal and be specific to certain areas of both HIV-1 and HIV-2 depending on target sequences. Further studies are needed to define the sensitivity and specificity of these tests' ability to detect HIV-2.

Table I: FDA approved assays for the quantification of HIV RNA

\begin{tabular}{|c|c|c|c|c|c|}
\hline Assay & Manufacturer & Technique & Sensitivity (copies/ml) & HIV-I Subtypes & HIV-2 \\
\hline AMPLICOR $[39,40]$ & Roche & RT-PCR & $50 \dagger-750,000$ & Group M (subtypes A-H) & Detected 3/4 HIV-2 [37] \\
\hline Versant HIV-I RNA 3.0 [4I] & Bayer & bDNA & $75-500,000$ & Group M (subtypes A-G) & No $[42]$ \\
\hline $\begin{array}{c}\text { NucliSens HIV RNA QT } \\
{[28,43]}\end{array}$ & BioMereiux & NASBA & I76-3.4 million & Group M (not subtype G) & YES [36] (subtype A) \\
\hline $\begin{array}{c}\text { COBAS AmpliPrep, Taqman } \\
\text { HIV-I [44] }\end{array}$ & Roche & RT-PCR & 48-10 million & Group M (subtypes A-H) & No $[3,45]$ \\
\hline RealTime HIV-I [45] & Abbott & RT-PCR & 40-10 million & $\begin{array}{l}\text { Group } M, N, O \text {, } \\
\text { recombinants }\end{array}$ & No [45] \\
\hline
\end{tabular}

NASBA: Nucleic acid sequence based amplification assay RT-PCR: Reverse transcription polymerase-chain reaction bDNA: Branched DNA assay

tThe standard assay can detect $400-750,000$ copies $/ \mathrm{ml}$ and the ultra-sensitive assay can detect 50-100,000 copies/ml. 
In our institution, patients are tested for HIV using the Bayer ADVIA Centaur HIV-1/O/2 EHIV EIA [38]. This was positive in our patient, but a western blot for HIV-1 was negative. The Versant branched DNA assay is our standard measure for HIV viral loads, but this technique did not quantify any viral RNA in this particular patient. Followup testing with a western blot specific for HIV-2 was positive and subsequent viral quantification based the Roche Amplicor system showed a significant viral load.

Our patient exemplifies the diagnostic difficulties of identifying HIV-2 in the United States. Fortunately, we were able to elucidate a history of Western African origin from our patient. All physicians involved in screening for HIV should be aware of the limitations between assays and know which test their institution uses. Clinicians need to have a high index of suspicion in patients with risk factors for HIV-2 to appropriately diagnose and treat the disease.

\section{Competing interests}

SC reports receiving grant support for an unrelated study from Bristol-Myers Squibb. All other authors declare there are no competing interests in this work. The present study was unfunded.

\section{Authors' contributions}

PC and SW participated in the research, writing, and editing of the manuscript. TF, SC, EK, and RK participated in the writing and editing of the manuscript. All authors read and approved the final manuscript.

\section{References}

I. Schmidt WP, Schim VANDERLM, Aaby P, Whittle H, Bakker R, Buckner M, Dias F, White RG: Behaviour change and competitive exclusion can explain the diverging HIV-I and HIV-2 prevalence trends in Guinea-Bissau. Epidemiol Infect 2008, | 36(4):55I-56|.

2. Factsheet C: 1998 [http://www.cdc.gov/hiv/resources/factsheets/ hiv2.htm].

3. Owen SM, Yang C, Spira T, Ou CY, Pau CP, Parekh BS, Candal D, KuehI D, Kennedy MS, Rudolph D, Luo W, Delatorre N, Masciotra S, Kalish ML, Cowart F, Barnett T, Lal R, McDougal JS: Alternative Algorithms for HIV Diagnosis Using Tests that are Licensed in the United States. J Clin Microbiol 2008.

4. DeParle J: In a World on the Move, a Tiny Land Strains to Cope. The New York Times; 2007.

5. Federation for American Immigration Reform [http:www.fairus.org/site/PageS erver?pagename $=$ research research9f8b sup\#legal]

6. Delwart EL, Orton S, Parekh B, Dobbs T, Clark K, Busch MP: Two percent of HIV-positive U.S. blood donors are infected with non-subtype B strains. AIDS Res Hum Retroviruses 2003, 19(1 2): 1065-1070.

7. Loeff MF Schim van der, Aaby P: Towards a better understanding of the epidemiology of HIV-2. Aids 1999, I 3(Suppl A):S69-84.

8. Kanki PJ, Travers KU, S MB, Hsieh CC, Marlink RG, Gueye NA, Siby T, Thior I, Hernandez-Avila M, Sankale JL: Slower heterosexual spread of HIV-2 than HIV-I. Lancet 1994, 343(8903):943-946.

9. Marlink R, Kanki P, Thior I, Travers K, Eisen G, Siby T, Traore I, Hsieh CC, Dia MC, Gueye EH: Reduced rate of disease development after HIV-2 infection as compared to HIV-I. Science 1994, 265(5 I 78): $1587-1590$.
10. Bienaime A, Colson P, Moreau J, Zandotti C, Pellissier JF, Brouqui P: Progressive multifocal leukoencephalopathy in HIV-2infected patient. Aids 2006, 20(9): $1342-1343$.

II. Moulignier A, Lascoux C, Bourgarit A: HIV type 2 demyelinating encephalomyelitis. Clin Infect Dis 2006, 42(II):e89-9I.

12. Kanki PJ, Barin F, M'Boup S, Allan JS, Romet-Lemonne JL, Marlink R, McLane MF, Lee TH, Arbeille B, Denis F: New human T-lymphotropic retrovirus related to simian T-lymphotropic virus type III (STLV-IIIAGM). Science I 986, 232(4747):238-243.

13. Ren J, Bird LE, Chamberlain PP, Stewart-Jones GB, Stuart DI, Stammers DK: Structure of HIV-2 reverse transcriptase at 2.35-A resolution and the mechanism of resistance to non-nucleoside inhibitors. Proc Natl Acad Sci USA 2002, 99(22): | 44 I0-I44II.

14. Witvrouw M, Pannecouque C, Switzer WM, Folks TM, De Clercq E, Heneine W: Susceptibility of HIV-2, SIV and SHIV to various anti-HIV-I compounds: implications for treatment and postexposure prophylaxis. Antivir Ther 2004, 9(I):57-65.

15. Adje-Toure CA, Cheingsong R, Garcia-Lerma JG, Eholie S, Borget MY, Bouchez JM, Otten RA, Maurice C, Sassan-Morokro M, Ekpini RE, Nolan M, Chorba T, Heneine W, Nkengasong JN: Antiretroviral therapy in HIV-2-infected patients: changes in plasma viral load, CD4+ cell counts, and drug resistance profiles of patients treated in Abidjan, Cote d'Ivoire. Aids 2003, I 7(SuppI 3):S49-54.

16. Desbois D, Roquebert B, Peytavin G, Damond F, Collin G, Benard A, Campa P, Matheron S, Chene G, Brun-Vezinet F, Descamps D: In vitro phenotypic susceptibility of human immunodeficiency virus type 2 clinical isolates to protease inhibitors. Antimicrob Agents Chemother 2008, 52(4): I545-I548.

17. Ntemgwa M, Brenner BG, Oliveira M, Moisi D, Wainberg MA: Natural polymorphisms in the human immunodeficiency virus type 2 protease can accelerate time to development of resistance to protease inhibitors. Antimicrob Agents Chemother 2007, 5 I (2):604-6I0.

18. Rodes B, Sheldon J, Toro C, Jimenez V, Alvarez MA, Soriano V: Susceptibility to protease inhibitors in HIV-2 primary isolates from patients failing antiretroviral therapy. J Antimicrob Chemother 2006, 57(4):709-7I3.

19. Identification of HIV-I group $O$ infection - Los Angeles county, California, 1996. MMWR Morb Mortal Wkly Rep 1996, 45(26):56I-565.

20. Loussert-Ajaka I, Ly TD, Chaix ML, Ingrand D, Saragosti S, Courouce AM, Brun-Vezinet F, Simon F: HIV-I/HIV-2 seronegativity in HIV-I subtype $O$ infected patients. Lancet 1994, 343(89 | 0): 1393-1394.

21. Schable C, Zekeng L, Pau CP, Hu D, Kaptue L, Gurtler L, Dondero T, Tsague JM, Schochetman G, Jaffe H: Sensitivity of United States HIV antibody tests for detection of HIV-I group $\mathrm{O}$ infections. Lancet 1994, 344(8933): 1333-1334.

22. Zouhair S, Roussin-Bretagne S, Moreau A, Brunet S, Laperche S, Maniez M, Barin F, Harzic M: Group o human immunodeficiency virus type $I$ infection that escaped detection in two immmunoassays. J Clin Microbiol 2006, 44(2):662-665.

23. Saville RD, Constantine NT, Cleghorn FR, Jack N, Bartholomew C, Edwards J, Gomez P, Blattner WA: Fourth-generation enzymelinked immunosorbent assay for the simultaneous detection of human immunodeficiency virus antigen and antibody. J Clin Microbiol 200I, 39(7):2518-2524.

24. Weber B, Orazi B, Raineri A, Thorstensson R, Burgisser P, Muhlbacher A, Areal C, Eiras A, Villaescusa R, Camacho R, Diogo I, Roth H], Zahn I, Bartel J, Bossi V, Piro F, Atamasirikul K, Permpikul P, Webber L, Singh S: Multicenter evaluation of a new 4th generation HIV screening assay Elecsys HIV combi. Clin Lab 2006, 52(9-10):463-473.

25. Yeom JS, Jun G, Chang Y, Sohn MJ, Yoo S, Kim E, Ryu SH, Kang HJ, Kim YA, Ahn SY, Cha JE, Youn ST, Park JW: Evaluation of a new fourth generation enzyme-linked immunosorbent assay, the LG HIV Ag-Ab Plus, with a combined HIV p24 antigen and anti-HIV-I/2/O screening test. J Virol Methods 2006, I37(2):292-297.

26. O'Brien TR, George JR, Epstein JS, Holmberg SD, Schochetman G: Testing for antibodies to human immunodeficiency virus type 2 in the United States. MMWR Recomm Rep I992, 4 I (RRI2): I-9.

27. Braun $P$, Ehret R, Wiesmann F, Zabbai F, Knickmann M, Kuhn R, Thamm S, Warnat G, Knechten H: Comparison of four commer- 
cial quantitative HIV-I assays for viral load monitoring in clinical daily routine. Clin Chem Lab Med 2007, 45(I):93-99.

28. Damond F, Gueudin M, Pueyo S, Farfara I, Robertson DL, Descamps D, Chene G, Matheron S, Campa P, Brun-Vezinet F, Simon F: Plasma RNA viral load in human immunodeficiency virus type 2 subtype A and subtype B infections. J Clin Microbiol 2002, 40(10):3654-3659.

29. Elbeik T, Alvord WG, Trichavaroj R, de Souza M, Dewar R, Brown A, Chernoff D, Michael NL, Nassos P, Hadley K, Ng VL: Comparative analysis of HIV-I viral load assays on subtype quantification: Bayer Versant HIV-I RNA 3.0 versus Roche Amplicor HIV-I Monitor version I.5. J Acquir Immune Defic Syndr 2002, 29(4):330-339.

30. Galli R, Merrick L, Friesenhahn M, Ziermann R: Comprehensive comparison of the VERSANT HIV-I RNA 3.0 (bDNA) and COBAS AMPLICOR HIV-I MONITOR I.5 assays on I,000 clinical specimens. J Clin Virol 2005, 34(4):245-252.

31. Gleaves CA, Welle J, Campbell M, Elbeik T, Ng V, Taylor PE, Kuramoto K, Aceituno S, Lewalski E, Joppa B, Sawyer L, Schaper C, McNairn D, Quinn T: Multicenter evaluation of the Bayer VERSANT HIV-I RNA 3.0 assay: analytical and clinical performance. J Clin Virol 2002, 25(2):205-216.

32. Gomes P, Palma AC, Cabanas J, Abecasis A, Carvalho AP, Ziermann R, Diogo I, Goncalves F, Lobo CS, Camacho R: Comparison of the COBAS TAQMAN HIV-I HPS with VERSANT HIV-I RNA 3.0 assay (bDNA) for plasma RNA quantitation in different HIV-I subtypes. J Virol Methods 2006, I35(2):223-228.

33. Berry N, Ariyoshi K, Jaffar S, Sabally S, Corrah T, Tedder R, Whittle $\mathrm{H}$ : Low peripheral blood viral HIV-2 RNA in individuals with high CD4 percentage differentiates HIV-2 from HIV-I infection. J Hum Virol 1998, I(7):457-468.

34. Popper SJ, Sarr AD, Travers KU, Gueye-Ndiaye A, Mboup S, Essex ME, Kanki PJ: Lower human immunodeficiency virus (HIV) type 2 viral load reflects the difference in pathogenicity of HIV-I and HIV-2. J Infect Dis 1999, I80(4): I I I6-II II.

35. Ruelle J, Mukadi BK, Schutten M, Goubau P: Quantitative realtime PCR on Lightcycler for the detection of human immunodeficiency virus type 2 (HIV-2). J Virol Methods 2004, I I 7(I):67-74.

36. Rodes B, Sheldon J, Toro C, Cuevas L, Perez-Pastrana E, Herrera I, Soriano V: Quantitative detection of plasma human immunodeficiency virus type 2 subtype A RNA by the Nuclisens EasyQ Assay (version I.I). J Clin Microbiol 2007, 45(I):88-92.

37. Roche : Summary Insert: AMPLICOR RT-PCR Version I.5.

38. Schappert J, Wians FH Jr, Schiff E, Smalley D, Gambardella R, Lee WM, Wu J, Keiser P, Peterson D, De Medina M, Baker L, Preisel-Simmons B: Multicenter evaluation of the Bayer ADVIA Centaur HIV I/O/2 enhanced (EHIV) assay. Clin Chim Acta 2006, 372(I-2): I58-166.

39. Mulder J, McKinney N, Christopherson C, Sninsky J, Greenfield L, Kwok S: Rapid and simple PCR assay for quantitation of human immunodeficiency virus type I RNA in plasma: application to acute retroviral infection. I Clin Microbiol 1994, 32(2):292-300.

40. Nolte FS, Boysza J, Thurmond C, Clark WS, Lennox JL: Clinical comparison of an enhanced-sensitivity branched-DNA assay and reverse transcription-PCR for quantitation of human immunodeficiency virus type I RNA in plasma. J Clin Microbiol 1998, 36(3):716-720.

4I. Pachl C, Todd JA, Kern DG, Sheridan PJ, Fong SJ, Stempien M, Hoo B, Besemer D, Yeghiazarian T, Irvine B: Rapid and precise quantification of HIV-I RNA in plasma using a branched DNA signal amplification assay. J Acquir Immune Defic Syndr Hum Retrovirol 1995, 8(5):446-454.

42. Bayer : Summary Insert: Versant HIV-I RNA 3.0.

43. van Gemen B, Kievits T, Nara P, Huisman HG, Jurriaans S, Goudsmit J, Lens P: Qualitative and quantitative detection of HIV-I RNA by nucleic acid sequence-based amplification. Aids 1993, 7(Suppl 2):S107-110.

44. Schumacher W, Frick E, Kauselmann M, Maier-Hoyle V, Vliet R van der, Babiel R: Fully automated quantification of human immunodeficiency virus (HIV) type I RNA in human plasma by the COBAS AmpliPrep/COBAS TaqMan system. J Clin Virol 2007, 38(4):304-3I2.

45. Gueudin M, Plantier JC, Lemee V, Schmitt MP, Chartier L, Bourlet T, Ruffault A, Damond F, Vray M, Simon F: Evaluation of the Roche
Cobas TaqMan and Abbott RealTime extraction-quantification systems for HIV-I subtypes. J Acquir Immune Defic Syndr 2007, 44(5):500-505.
Publish with Bio Med Central and every scientist can read your work free of charge

"BioMed Central will be the most significant development for disseminating the results of biomedical research in our lifetime. "

Sir Paul Nurse, Cancer Research UK

Your research papers will be:

- available free of charge to the entire biomedical community

- peer reviewed and published immediately upon acceptance

- cited in PubMed and archived on PubMed Central

- yours - you keep the copyright

Submit your manuscript here:

http://www.biomedcentral.com/info/publishing_adv.asp 